\title{
About Innovation Method of the Mental Hygiene for Preventive to used Alcohol and Drug of Substances at the Teenagers
}

\author{
Moskvitin PN* \\ Novosibirsk Research Institute of Hygiene Novosibirsk, Russian Federation, Russia
}

Received: 阱January 10, 2019; Published: 阱January 25, 2019

*Corresponding author: Moskvitin PN, Novosibirsk Research Institute of Hygiene Novosibirsk, Russian Federation, Russia

\section{Opinion}

Social and medical problems associated with the use of drugs and alcohol are observed in many countries of the world. From the point of view of existential-humanistic analysis, the high demand for the use of psychoactive substances is a marker of deep unresolved social and psychological problems in many people who have lost the true meaning of life [1]. It is noted that the state of existential frustration of public consciousness characterizes the development of "risk society" [2] where $100 \%$ of drug addicts and $80 \%$ of alcoholics reveal the phenomenon of "existential vacuum" [3] which requires great attention to the development of measures to prevent addictive behavior. It is proved that the process of anesthesia in children and adolescents is influenced by the styles of family education [4-6]. These studies consider the characterological features of personality, character accentuation, styles of family education, influencing the formation of drug dependent behavior [7]. The role of various emotional States that can provoke or block addictive behavior of adolescents is revealed [8].

It is established that early alcoholism and substance abuse lead to changes in the motivational sphere of adolescents 15-17 years, where there is a narrowing of the time perspective [8-10]. Distribution of objects of satisfaction of needs occurs at them in" the near future "and in" the actual period", not exceeding the period of 1-2 years. It is found that adolescents with addictive tendencies have reduced the need for communication, but the motive of self-autonomy is increased [11]. Taking into account the above circumstances, we have developed a method of "preventive psychodrama" $[12,13]$. On its basis, a program of training aimed at developing the motivation of non-use of psychoactive substances. This task of psychoprophylaxis was achieved by staging the life experience of the participants. Psychodramatic's playing of roles was aimed at activation of mental processes, development of existential maturity, moral and harmonious development of personality of participants of training, their positive socialization. The program forms the experience of social construction of interpersonal and inter-group relations, the search for a positive way out of the problem situation, as well as obtaining positive emotions. At the climax of the conflict, a safe and constructive atmosphere of a "positive meeting" on the theme of the dynamics of the psychodrama is being created. This helps to build a relationship of adolescents in three aspects:

a. Attitude;

b. The relation to the other, and

c. The attitude of the society.

Conducting a training "preventive psychodrama" on an improvised stage is a synthetic psychoprophylactic, collective art form based on the life experience of each member of the group. The unique combination of three components-creative activity, selforganization and spontaneity (congruence) is the most important difference of the method of "preventive psychodrama" developed by us in comparison with other methods and techniques of group primary prevention of dependence on psychoactive substances $[1,6,9]$. The leading role allows to support the process of personal transformation in the process of creative play in the group and is a kind of "coaching of social competence". The combination of, on the one hand, some given socio-psychological situations, typical conflicts that arise during communication in adolescence and on the other hand, joint discussion and adoption of the most effective approaches in the development of sustainable cognitive-behavioral models of constructive conflict resolution create an advantage of the method of "preventive psychodrama". Interpersonal relationships in the group are key to the process of change. In fact, in the group of 
almost every teenager there is a kind of "movement on logical levels" up, down and horizontally that is, changes in self-identification cause the expansion of the range of resource beliefs, resulting in the formation of new abilities that characterize social competence, and the replacement of pathological behavioral patterns with new, more adaptive.

On the other hand, it is the study of so-called standard conflict situations that helps to make the reverse movement-from the banal change of behavior in this interpersonal environment to the awareness of other, more adaptive and resource abilities. This method helps to neutralize negative beliefs and obtain positive reinforcement from both internal resources and group approval, thus completing positive self-identification. Another feature of the method of "preventive psychodrama" is to create a special situation in the group "positive consultation". This point is achieved by the "actors" and the leading training methodical reception "Stop action". Active discussion in the climax of the development of microtomy when there is still a lot of options and behavioral strategies allows you to select the most appropriate. Thus, the training of the "preventive psychodrama" develops skills of social cooperation. Features of the psychodramatic approach in the study of a typical conflict and the subsequent sharing provide an opportunity for active living and playing the safest ways to resolve interpersonal conflicts in a jointly created reality. Humanistic orientation method allows to combine the existential potential of group psychoprophylaxis with elements of communicative training, which creates the psycho-hygienic advantage of this technology compared to the methods of health education and promotion, more focused on the few effective negative information approach.

\section{References}

1. Karvasarsky BD (1998) Psychotherapeutic Encyclopedia. SPB: Peter KOM pp. 752.

\section{ISSN: 2574-1241}

DOI: 10.26717/BJSTR.2019.13.002427

Moskvitin PN. Biomed J Sci \& Tech Res

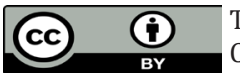

This work is licensed under Creative Commons Attribution 4.0 License

Submission Link: https://biomedres.us/submit-manuscript.php
2. Bek U (2000) Obshhestvo risk. On the road to another modern. M Progress-Tradition pp. 384.

3. Frankl V (1990) Chelovek v poiskah smysla M.

4. Koposov RA (2005) Psihologicheskie i mediko-social'nye aspekty addiktivnogo povedenija podrostkov: avtoref. disskand Med nauk: 19.00.05 / Koposov Roman Aleksandrovich. Arhangel'sk 18 s.

5. Mendelevich VD (2001) Psihologija deviantnogo povedenija. M MED press (in Russian).

6. Sirota NA, Jaltonskij VM, Hazhilina II, Viderman NS (1983) Profilaktika narkomanii u podrostkov M "Genezis"; 2001. (in Russian) Lichko AE, Psihopatii i akcentuacii haraktera u podrostkov. L Medicina pp. 316.

7. Rerke VI Osobennosti motivacionno-potrebnostnoj sfery lichnosti podrostka s narkozavisimym povedeniem: avtoref. Disskand psihol nauk: 19.00.07.

8. Rerke VI (2003) Features of the motivational-need sphere of the personality of a teenager with drug-addicted behavior: author. disscand. psychol. Sciences: 19.00.07 / Rerke Viktoriya Igorevna. Irkutsk p.19.

9. Kulakov SA (1996) Psihoterapija i psihoprofilaktika addiktivnogo povedenija u podrostkov: prakt. posobie; pod nauch. red. L.I. Vassermana M Folium 48s.

10. Tomilova SA (2004) Psihologo-pedagogicheskaja korrekcija samosoznanija podrostkov, upotrebljajushhih narkoticheskie veshhestva: avtoref. Disskand psih nauk: 19.00.01 / Tomilova Svetlana Aleksandrovna. Krasnojarsk 19.

11. Gruzd LV (2004) Cennostnye orientacii narkozavisimoj lichnosti: avtoref. diss ... kand. psihol. nauk: 19.00.01; 19.00.05 / Gruzd Larisa Vasil'evna. Kazan 23s. Russia.

12. Moskvitin PN, Tsygankov BD, Sirota NA (2011) Metod profilakticheskoj psihodramy v preduprezhdenii zavisimosti ot psihoaktivnyh veshhestv u detej i podrostkov. M Medicina 248s (in Russian).

13. Moskvitin PN (2012) Sposob provedenija gruppovogo psihologicheskogo treninga po metodu profilakticheskaja psihodrama “. Patent na izobretenie RF No. 2466752, zajavka No. 2011136339, prioritet izobretenija 31 avgusta 2011 goda, zaregistrirovan v Gosudarstvennom reestre izobretenij Rossijskoj Federacii 20 nojabrja (in Russian).

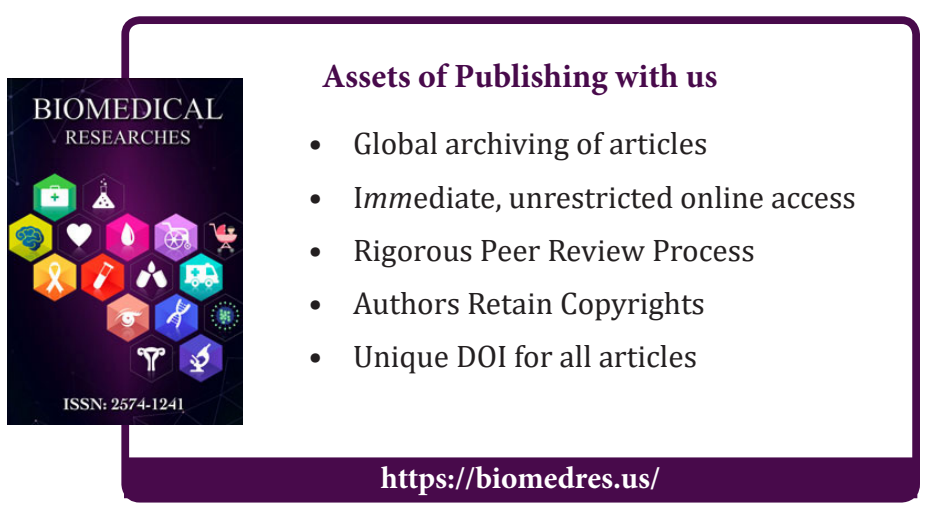

Cite this article: Moskvitin PN. About Innovation Method of the Mental Hygiene for Preventive to used Alcohol and Drug of Substances at the 